Andriana, et al/Jurnal Ekonomi Syariah Teori dan Terapan Vol. 6 No. 3 Maret 2019: 428-445; IMPLEMENTASI KOMPONEN MAQASHID SYARIAH TERHADAP KESEJAHTERAAN PADAKARYAWAN YAYASAN NURUL HAYAT SURABAYA

\title{
IMPLEMENTASI KOMPONEN MAQASHID SYARIAH TERHADAP KESEJAHTERAAN PADAKARYAWAN YAYASAN NURUL HAYAT SURABAYA ${ }^{1}$
}

\author{
Novita Andriana \\ Departemen Ekonomi Syariah - Fakultas Ekonomi dan Bisnis - Universitas Airlangga \\ Email: novita.andriana-2015@feb.unair.ac.id \\ Ari Prasetyo \\ Departemen Ekonomi Syariah - Fakultas Ekonomi dan Bisnis - Universitas Airlangga \\ Email: ari.prasetyo@feb.unair.ac.id
}

\begin{abstract}
:
The purpose of this research is to determine the welfare of employees at the Nurul Hayat Foundation, which is viewed from the perspective of the maqashid sharia, which is about religion, soul, intelligence, generation, and wealth. The research method used is a case study with a descriptive qualitative approach. Qualitative descriptive is researching a group of people, an object, a condition, or something in the present. The purpose of this descriptive research is to make an accurate description of the facts, traits and relationships between events that occur in real life. This study uses the interview process in primary data collection. The interview process was conducted with 7 employees of the Nurul Hayat Foundation. The results of this research are the Nurul Hayat Foundation as a sharia institution that always prioritizes religious values. Nurul Hayat Institution is the welfare of its employees by implementing policies for its employees. Through these policies all employees feel prosperous and fulfilled their needs as measured by the five indicators of maqashid sharia, namely maintaining religion, maintaining the soul, maintaining intelligence, maintaining generation, and maintaining wealth.
\end{abstract}

Keywords: Employment, Employee Welfare, Islamic Welfare, Maqashid Sharia

\section{PENDAHULUAN}

Setiap negara mempunyai sistem

yang berbeda-beda untuk mengukur

pertumbuhan dan mensejahterakan

perekonomian negara. Dalam

kesejahteraan ekonomi terdapat sebuah pengukuran kemakmuran di setiap negara, misalnya pendapatan per kapita di sebuah negara sebagai pengukur kemakmuran. Pendapatan suatu negara atau disebut juga pendapatan nasional dapat diartikan sebagai jumlah barang dan jasa yang dihasilkan suatu negara pada periode tertentu. Jumlah barang dan jasa yang dihasilkan suatu negara karena adanya perusahaan. Suatu perusahaan selalu membutuhkan sumber daya manusia di dalamnya yaitu tenaga kerja atau karyawan.

Tenaga kerja atau karyawan merupakan aset perusahaan yang sangat penting bagi manajemen dalam menjalankan aktivitas perusahaan. Karyawan selaku sumber daya manusia harus diperhatikan dalam berbagai segi karena tanpa kehadiran sumber daya

\footnotetext{
1 Jurnal ini merupakan bagian dari skripsi Novita Andriana, NIM: 041511433175, yang diuji pada tanggal 22 Juli 2019.
} 
Andriana, et al/Jurnal Ekonomi Syariah Teori dan Terapan Vol. 6 No. 3 Maret 2019: 428-445; IMPLEMENTASI KOMPONEN MAQASHID SYARIAH TERHADAP KESEJAHTERAAN PADAKARYAWAN YAYASAN NURUL HAYAT SURABAYA

manusia roda perusahaan tidak akan berjalan dengan lancar. Salah satu upaya perusahaan adalah memberikan kesejahteraan yang memadai kepada karyawannya, agar karyawan memiliki motivasi kerja, prestasi kerja meningkat, berdisiplin tinggi, dan bersikap loyal dalam menunjang suatu tujuan perusahaan. Undang-Undang Nomor 13 tahun 1998 menjelaskan kesejahteraan merupakan suatu tata kehidupan dan penghidupan sosial baik material maupun spiritual yang diliputi rasa keselamatan, kesusilaan, dan ketentraman lahir batin yang memungkinkan bagi setiap warga negara untuk mengadakan pemenuhan jasmani, rohani, dan sosial yang sebaikbaiknya bagi diri, keluarga serta masyarakat dengan menjujung tinggi hak dan kewajiban asasi manusia sesuai dengan Pancasila.

Islam sebagai agama yang universal dan komprehensif. Kesempurnaan ajaran Islam dikarenakan Islam tidak saja mengatur aspek ibadah ritual semata, tetapi seluruh kehidupan manusia yang meliputi sosial, politik, budaya, hukum, ekonomi, dan lainlain.Menurut Al Ghazali beliau berpendapat (Karim, 2007:62) bahwa manusia yang memiliki tujuan untuk mencapai kesejahteraan (maslahah) yaitu dengan melakukan dan pemeliharaan pada lima tujuan dasar (maqashid syariah) yang meliputi agama (al-dien), jiwa (an-nafs), intelek atau akal (al-aql), keluarga dan keturunan (an-nasl) dan harta (al-maal)". Beliau menitik beratkan bahwa yang utama sesuai tuntunan wahyu adalah kebaikan dunia dan akhirat (maslahat al-din wa aldunya) merupakan tujuan utamanya.

Seperti yang dijelaskan pada QS AnNisa ayat 9 , kesejahteraan dapat diperoleh hanya dengan ketaqwaan kepada Allah SWT. Allah meminta kepada hambanya untuk memperhatikan kesejahteraan generasi yang akan datang. Setiap pemimpin suatu perusahaan diharapkan memperhatikan hak-hak yang menjadi dasar kebutuhan karyawannya, agar mengantarkan pada kebahagiaan(falah). Dengan hal inilah pemimpin perusahaan dapat menegakkan keharmonisan antara kebutuhan moral dan kebutuhan material karyawan serta terjalankannya prinsip keadilan dan persaudaran dalam berbagai aktifitas suatu perusahaan.

Untuk melihat kesejahteraan karyawan maka dilakukan penelitian pada perusahaan syariah. Perusahaan yang berorientasi Islami yang menjadi objek dalam penelitian ini adalah Yayasan Nurul Hayat. Yayasan Nurul Hayat sebagai contoh perusahaan/lembaga kesejahteraan umat dalam bidang layanan sosial dan dakwah. Yayasan Nurul Hayat berdiri pada tahun 2001. Pada sejak awal didirikan sudah dicita-citakan untuk menjadi lembaga milik ummat yang mandiri. Gaji karyawan pada Yayasan Nurul Hayat dipenuhi oleh hasil penjualan dari unit 
Andriana, et al/Jurnal Ekonomi Syariah Teori dan Terapan Vol. 6 No. 3 Maret 2019: 428-445; IMPLEMENTASI KOMPONEN MAQASHID SYARIAH TERHADAP KESEJAHTERAAN PADAKARYAWAN YAYASAN NURUL HAYAT SURABAYA

usaha. Donasi dari masyarakat berupa zakat, infak dan shodaqoh (ZIS) $100 \%$ tersalurkan untuk mendukung program layanan sosial dan dakwah Yayasan Nurul Hayat.

permasalahanyaitu bagaimana kesejahteraan karyawan yang ditinjau dari perspektif maqashid syariah pada Yayasan Nurul Hayat?

Tujuan penelitian ini adalah mengetahui kesejahteraan karyawan pada Yayasan Nurul Hayat. Dalam penelitian ini peneliti berfokus pada bagaimana pimpinan suatu perusahaan memenuhi hakhak dan kewajiban atau kebutuhan karyawannya berdasarkan perspektif maqashid syariah.

\section{LANDASAN TEORI}

Peran tenaga kerja atau karyawan sangat dibutuhkan untuk menentukan kesuksesan berdirinya suatu perusahaan. BPS (Badan Pusat Staistik 2014) membagi tenaga kerja yaitu:

1. Tenaga kerja penuh adalah tenaga kerja yang mempunyai jumlah jam kerja > 35 jam dalam seminggu dengan hasil kerja tertentu sesuai dengan uraian tugas.

2. Tenaga kerja tidak penuh atau setengah pengangguran adalah tenaga kerja dengan jam kerja $<35$ jam seminggu
3. Tenaga Kerja yang belum bekerja atau sementara tidak bekerja adalah tenaga kerja dengan jam kerja $0>1$ jam per minggu

Karyawan atau human capital menjadi sangat penting karena dapat menghasilkan nilai lebih untuk perusahaan, maka peran dan fungsi karyawan bertujuan untuk membantu memperlancar produktivitas dan memaksimalkan kinerja serta memanfatkan waktu secara efektif.

\section{Menurut Soedarjadi}

(2009:15) karyawan dalam suatu perusahaan atau organisasi memiliki peran dan fungsi diantaranya:

1. Melaksanakan pekerjaan sesuai dengan tugas dan perintah yang diberikan.

2. Menjaga ketertiban dan keamanan di lingkungan perusahaan demi kelangsungan perusahaan.

3. Bertanggung jawab pada hasil produksi.

4. Menciptakan ketenangan kerja di perusahaan.

Kesejahteraan karyawan (employee's well-being), kesejahteraan dikonsepkan sebagai suatu konsep yang dibangun secara global dan dioperasikan dengan memasukan kepuasan kerja karyawan, kepuasan keluarga dan kesejahteraan fisik maupun kesejahteraan secara psikoligis. Sedangkan kesejahteraan karyawan menurut Hasibuan (2003), adalah balas jasa pelengkap (material dan non 
Andriana, et al/Jurnal Ekonomi Syariah Teori dan Terapan Vol. 6 No. 3 Maret 2019: 428-445; IMPLEMENTASI KOMPONEN MAQASHID SYARIAH TERHADAP KESEJAHTERAAN PADAKARYAWAN YAYASAN NURUL HAYAT SURABAYA

material).

$$
\text { Menurut Qardhawi (1997:107), }
$$

bekerja adalah bagian dari ibadah dan jihad jika seorang pekerja bersikap konsisten terhadap peraturan Allah, suci niatnya dan tidak melupakan-Nya. Dengan bekerja manusia dapat melaksanakan tugas kekhalifahannya, menjaga diri dari maksiat, dan meraih tujuan yang sangat besar. Suatu pekerjaan kecil jika dilaksanakan dengan professional akan lebih baik daripada pekerjaan besar tapi dikerjakan secara tidak professional. Hal tersebut sesuai dengan sabda Rasulullah SAW "sebaikbaiknya pekerjaan adalah yang dilakukan penuh ketekunan walaupun sedikit demi sedikit".

Profesionalisme bekerja dicirikan dalam tiga hal yaitu:

a. Kafa'ah, yaitu cakap atau ahli dalam bidang pekerjaan yang dilakukan. Hal ini dapat diperoleh melalui pendidikan, pelatihan dan pengalaman.

b. Himatul 'amal memiliki semangat atau etos kerja yang tinggi. Hal ini diraih dengan jalan menjadikan motivasi ibadah sebagai pendorong utama dalam bekerja disamping motivasi untuk mendapatkan penghargaan (reward) dan menghindari hukuman (punishment).

C. Amanah, diperoleh dengan menjadikan tauhid sebagai unsur pengontrol utama tingkah laku.

P3EI (2008:4-12) menjelaskan pandangannya tentang kesejahteraan sebagai berikut:

1. Kesejahteraan yang merupakan tujuan dari ekonomi konvensional sebagai prespektif yang hedonis dan matearilisme murni, sehingga keadaan sejahtera terjadi manakala manusia memiliki keberkelimpahan (tidak sekedar kecukupan) material sehingga dalam penyediaan barang dan jasa memberikan keunggulan dalam maksimasi kekayaan, kenikmatan fisik dan dunia semata, serta kepuasan hawa nafsu.

2. Menurut kapitalisme demokratik mengartikan kesejahteraan sebagai suatu keadaan yang membahagiakan setiap individu. Kebebasan individu merupakan tujuan utama yang mencakup beberapa hal yaitu: kebebasan politik, kebebasan ekonomi, kebebasan berpikir, dan kebebasan personal.

3. Menurut sudut pandang sosialisme, kesejahteraan diartikan sebagai suatu keadaan yang membahagiakan masyarakat secara kolektif. Paham sosialisme berkeyakinan konflik individu yang diwarnai dengan matearilistik harus dilebur menjadi kepentingan kolektif dan memandang perlunya penghapusan 
hak milik pribadi.

4. Menurut sudut pandang Islam, kesejahteraan diistilahkan dengan falah yang berarti kemenangan, kemuliaan, kesuksesan, yaitu keberkahan dalam jangka panjang dunia dan akhirat, sehingga tidak hanya memandang aspek material saja namun lebih menekankan pada aspek spiritual atau religius dalam hidup.

Adam Smith, dalam bukunya "The Wealth of Nation" mengemukakan kesejahteraan masyarakat akantercapai bila dipenuhi empat prinsip ekonomi dasar yaitu: (1)Prinsip keseimbangan produksi dankonsumsi, (2)Prinsip manajemen tenaga kerja, (3)Prinsip manajemen modal, (4)Prinsip kedaulatan ada di tangan rakyat.

Zadjuli (2006) menjelaskan indikator kesejahteraan yangditurunkan dari nilai-nilai al-Qur'an sebagai berikut :

1. Hifzud-dien, memelihara nilai-nilai agama dan melaksanakan ajarannya dalam hal bekerja untuk mencapai ekonomi keluarga yang tentram dan tenang (hifzun-nabal).

2. Hifzun-nafs, bertumbuhnya nilai-nilai yang memelihara keselamatan jiwa dalam rumah tangga atau masyarakat yang ditandai dengan angka kesakitan didalamnya.

3. Hifz-'aql, menciptakan nilai-nilai yang menjadikan pemikiran manusia yang hebat yang didasarkan pada kewajiban untuk menuntut ilmu dan dijadikan pedoman untuk menjalani hidup dalam ridho Allah SWT.

4. Hifz-maal, membangun nilai-nilai yang mampu menjamin pengembangan perekonomian keluarga atau masyarakat yang saling menguntungkan dimana ditandai dengan terpenuhinya kebutuhan hidup yang hasilnya diperoleh dari aktivitas ekonomi yang halal dan di ridhoi oleh Allah SWT.

5. Menegakkan nilai-nilai yang bersifat bebas memilih, beradab dan bermoral tinggi dalam membangun kebersamaan dan kekeluargaan dalan tatanan masyarakat, berbangsa, dan bernegara.

Secara terminologi, terdapat beberapa pengertian tentang maqashid syariah yang dikatakan oleh beberapa ulama terdahulu yaitu sebagai berikut:

1. Imam Al-Ghazali

Penjagaan terhadap maksud dan tujuan syariah adalah upaya mendasar untuk bertahan hidup, menahan faktor-faktor kerusakan dan mendorong terjadinya kesejahteraan.

2. Imam Al-Syatibi

Al-Maqashid terbagi menjadi dua yaitu pertama berkaitan dengan maksud Tuhan selaku pembuat syariah, dan kedua berkaitan dengan maksud mukallaf. 
3. 'Maqashid syariah merupakan tujuantujuan yang telah ditetapkan oleh syariah untuk dicapai demi kemaslahatan manusia.

4. Abdul Wahab Kallaf

Tujuan umum ketika Allah menetapkan hukum-hukumnya adalah untuk mewujudkan kemaslahatan manusia dengan terpenuhinya kebutuhan yang dharuriyyah, hajjiyah, dan tahsiniyah.

Dari beberapa pengertian diatas, dapat disimpulkan bahwa maqashid syariah adalah tujuan Allah selaku pencipta syariah untuk memberikan kemaslahatan manusia yaitu dengan terpenuhinya kebutuhan dharuriyyah, hajiyyah, dantahsiniyyah agar manusia menjadi hamba Allah yang baik dan hidup dalam kebaikan.

Para ahli ushul figh meneliti dan menetapkan ada lima unsur pokok yang harus diperhatikan. Kelima nya berasal dari Al-Qur'an dan merupakan tujuan syariah (maqashid syariah). Kelima pokok tersebut merupakan suatu hal yang harus dijaga dalam kehidupan manusia. Al-Syatibi membagi maqashid syariah menjadidharuriyyat, hajiyyat, dan tahsiniyyat.

1. Kebutuhan Dharuriyyat (Primer)

Kebutuhan dharuriyyat atau primer merupakan kebutuhan yang paling utama. Kebutuhan ini harus dapat terpenuhi agar manusia dapat hidup dengan layak dan tidak terjadi ketimpangan atau mengancam keselamatan umat manusia baik di dunia maupun di akhirat. Kebutuhan ini meliputi hal-hal yang berkaitan dengan pemeliharaan agama (aldien), jiwa (nafs), akal (aql), keturunan (nasl) dan harta (maal).

2. Kebutuhan Hajiyyat (Sekunder)

Kebutuhan hajiyyat atau sekunder pada dasarnya merupakan pelengkap yang mengokohkan, menguatkan serta melindungi jenjang kebutuhan dharuriyyat yang dimaksudkan untuk memudahkan kehidupan dan menghilangkan kesulitan terhadap ke lima unsur pokok maqashid syariah.

3. Kebutuhan Tahsiniyyat (Tersier)

Kebutuhan tahsiniyyat atau tersier merupakan kebutuhan yang apabial tidak terpenuhi tidak mengancam kelima macam unsur pokok maqashid syariah serta tidak pula menimbulkan kesulitan bagi kehidupan umat manusia.

Berdasarkan hakekatnya kelompok dharuriyyat, hajiyyat dan tahsiniyyat dimaksudkan memelihara kelima unsur pokok tersebut. Menurut Al-Syatibi penetapan kelima pokok diatas didasarkan atas dalil dalil Al-Quran dan Hadits. Adapun dijelaskan kelima pokok kemaslahatan dengan peringkatnya masing-masing (Wibowo, 2012:15-18) sebagai berikut: 
1. Memelihara Agama (Hifzu Al-Dien)

a) Memelihara agama dalam tingkat dharuriyyat, yaitu memelihara dan melaksanakan kewajiban keagamaan seperti melaksanakan shalat lima waktu wajib bagi seorang muslim.

b) Memelihara agama dalam tingkathajiyyat, yaitu melaksanakan ketentuan agama dengan maksud menghindari kesulitan seperti melaksanakan shalat jama' dan shalat qashar bagi orang yang sedang dalam perjalanan.

c) Memelihara agama tingkat tahsiniyyat yaitu mengikuti petunjuk agama serta melaksanakan kewajiban kepada Allah SWT seperti menutup aurat baik ketika shalat maupun tidak. Jika tidak dilakukan maka tidak akan mengancam eksistensi agama dan tidak menyulitkannya.

Dalam sebuah perusahaan

implementasi hifz al-dien untuk mengukur kesejahteraan yaitu seperti kebijakankebijakann perusahaan yang berbasis pada nilai-nilai islam, tersedianya fasilitas ibadah, tersedianya waktu yang cukup untuk melaksanakan sholat, mengadakan pengajian, dan pembayaran zakat.

2. Memelihara Jiwa (Hifzu al-Nasl)

a) Memelihara jiwa dalam tingkat dharuriyyat, misalnya dengan cara memenuhi kebutuhan pokok agar hidup sentosa seperti makanan untuk mempertahankan hidup, pakaian untuk dikenakan. Jika kebutuhan pokok ini diabaikan, maka akan dapat berakibat terancamnya jiwa manusia.

b) Memelihara jiwa, dalam tingkat hajiyyat, misalnya dengan cara menikmati makanan dan minuman yang lezat dan atau pakaian yang nyaman. Jika diabaikan, maka tidak akan mengancam eksistensi manusia, hanya mempersulitnya.

c) Memelihara jiwa dalam tingkat tahsiniyyat, misalnya ditetapkannya tata cara makan dan minum yang benar. Jika diabaikan maka tidak akan mengancam eksistensi jiwa manusia ataupun mempersulitnya.

Dalam sebuah perusahaan implementasi hifz al-nafs untuk mengukur kesejahteraan yaitu seperti menjaga keselamatan dan kesehatan karyawan, adanya asuransi kesehatan, tersedianya fasilitas makan atau uang makan dan fasilitas transportasi/akomodasi.

3. Memelihara Akal (Hifzu al-Aql)

a) Memelihara akal dalam peringkat dharuriyyat, misalnya diharamkan untuk mengkonsumsi minuman keras dan obat-obatan terlarang. Jika diabaikan maka akan berakibat terancamnya eksistensi 
Andriana, et al/Jurnal Ekonomi Syariah Teori dan Terapan Vol. 6 No. 3 Maret 2019: 428-445; IMPLEMENTASI KOMPONEN MAQASHID SYARIAH TERHADAP KESEJAHTERAAN PADAKARYAWAN YAYASAN NURUL HAYAT SURABAYA

akal manusia.

b) Memelihara akal dalam tingkathajiyyat, seperti dengan cara menuntut ilmu pengetahuan sehingga dapat mempermudah seseorang dalam mencari pekerjaan dimasa yang akan datang.

c) Memelihara akal dalam tingkat tahsiniyyat, misal menyibukkan diri dengan kegiatan yang bermanfaat serta dapat menambah produktifitas seperti pengembangan keilmuan.

Dalam sebuah perusahaan implementasi hifz al-aql untuk mengukur kesejahteraanyaitu sepertipengembangan skill karyawan, adanya pelatihan atau training karyawan, fasilitas berupa akomodasi atau vang saku bagi peserta pelatihan

4. Memelihara Keturunan (Hifzu al-Nas/)

a) Memelihara keturunan tingkat dharuriyyat, seperti disyariatkan untuk menikah dalam agama. Hal tersebut agar terhindar dari adanya perbuatan zina diluar nikah. Apabila hal ini diabaikan, maka akan mengancam eksistensi keturunan.

b) Memelihara keturunan dalam tingkat hajiyyat, seperti ditetapkannya adanya ketentuan mahar dan menyebutkan mahar tersebut bagi suami pada waktu akad nikah pernikahan.

c) Memelihara keturunan dalam tingkat tahsiniyyat, seperti adanya khitbah sebelum melakukan pernikahan dan walimah (resepsi) dalam pernikahan. Jika hal ini diabaikan, maka tidak akan mengancam eksistensi keturunan dan tidak pula mempersulitnya.

Dalam sebuah perusahaan implementasi hifz an-nasl untuk mengukur kesejahteraan yaitu seperti pemberian fasilitas dan cuti bagi karyawan yang sedang hamil, dan asuransi atau biaya untuk anggota keluarga karyawan.

5. Memelihara Harta (Hifzu al-Maal)

a) Memelihara harta dalam tingkat dharuriyyat, seperti disyariatkan mengenai tata cara memperoleh harta yang halal, kepemilikan harta dan larangan mengambil harta orang lain dengan cara yang tidak sah. Apabila dilanggar, maka berakibat terancamnya eksistensi harta.

b) Memelihara harta tingkathajiyyat, seperti disyariatkannya melakukan transaksi sesuai aturan syariah seperti akad murabahah, salam, istishna dll. Dan disyariatkannya melakukan pengeluaran harta sesuai dengan ajaran Islam. Apabila cara ini tidak dilaksanakan, maka tidak akan mengancam eksistensi harta. 
c) Memelihara harta dalam tingkat tahsiniyyat, seperti ketentuan tentang menghindarkan diri dari hal penipuan. Hal ini erat kaitannya dengan moral dan etika.

Dalam sebuah perusahaan

implementasi hifz al-maal untuk mengukur kesejahteraan yaitu sepertitepat waktu dalam pemberian gaji, kecukupan gaji, bonus atau insentif untuk karyawan.

Kesejahteraan menurut Imam AlGhazali adalah tercapainya kemaslahatan. Tercapainya kemaslahatan merupakan terpeliharannya maqashid syariah atau lima tujuan dasar, yakni yang terdiri dari agama, jiwa, akal, keturunan dan harta.Harta merupakan salah satu sarana yang sangat penting dalam mencapai kesejahteraan manusia. Tetapi, harta juga bisa menyebabkan malapetaka bagi manusia. Oleh sebab itu, Imam Al-Ghazali menempatkan harta pada urutan yang kelima dalam maqashid syariah. Keimanan (agama) dan harta sangat dibutuhkan dalam kehidupan manusia. Namun, keimanan tetap menjadi yang utama, karena dengan adanya iman dapat menghantarkan atau mengelola harta sesuai syariat Islam.Islam mengkehendaki suatu kuantitas serta kualitas yang wajar. Sebagaimana Allah SWT berfirman dalam surat Al-Furqan [25]:67 yaitu:

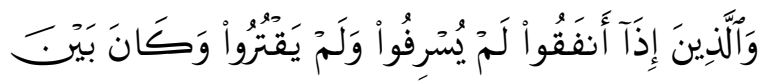

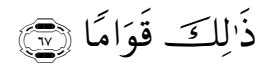

wallażina iżā anfaqụ lam yusrifụ wa lam yaqturụ wa kāna baina żālika qawāmā "Dan (termasuk hamba-hamba Tuhan Yang Maha Pengasih) orang-orang yang apabila menginfakkan (harta), mereka tidak berlebihan, dan tidak (pula) kikir, di antara keduanya secara wajar"

Maksud ayat tersebut adalah hendaknya orang-orang mukmin dalam menafkahkan hartanya tidak boros dan tidak pula kikir, tetapi tetap memelihara keseimbangan antara kedua sifat yang buruk tersebut (Tafsir Lengkap Departemen Agama).

Zadjuli (2006) menjelaskan bahwa indikator kesejahteraan yang diturunkan dari nilai-nilai al-Qur'an (maqashid syariah) sebagai berikut :

1. Memelihara nilai-nilai agama dan melaksanakan ajaran-ajarannya (hifzud-dien) dalam bekerja untuk menciptakan ekonomi keluarga yang sakinah, mawaddah, wa rahma penuh ketentraman dan ketenangan (hifzun-nabal)

2. Menumbuhan nilai-nilai yang mampu memelihara keselamatan jiwa dalam rumah tangga/masyarakat (hifzunnafs) yang ditandai oleh angka kesakitan dalam rumah tangga/masyarakat.

3. Menegakkan nilai-nilai yang menjamin pemikiran manusia yang 
Andriana, et al/Jurnal Ekonomi Syariah Teori dan Terapan Vol. 6 No. 3 Maret 2019: 428-445; IMPLEMENTASI KOMPONEN MAQASHID SYARIAH TERHADAP KESEJAHTERAAN PADAKARYAWAN YAYASAN NURUL HAYAT SURABAYA

jenius (hifz-'aql) yang ditandai oleh terpenuhinya kewajiban menuntut ilmu untuk mendapatkan pengetahuan dan pengalaman yang dapat dijadikan sandaran dalam mencari kehidupan yang diridhoi Allah SWT.

4. Membangun nilai-nilai yang mampu menjamin pengembangan ekonomi kelvarga/masyarakat yang saling menguntungkan (hifz-maal) yang ditandai oleh terpenuhinya kebutuhan hidup rumah tangga yang diperoleh dari aktivitas ekonomi yang diridhoi Allah (rizqi halalan tayyibah)

5. Membangun nilai-nilai yang bebas memilih (bersikap sesuai dengan kebenaran yang diyakini) santun, beradab dan bermoral tinggi (altahsiniyyat) dalam tatanan kebersamaan dan membangun nilai-nilai kekeluargaan dalam peri kehidupan bermasyarakat, berbangsa dan bernegara (alhajiyyat). Hal ini ditandai dengan terjalinnya silahturahmi antara anggota masyarakat, saling tolong menolong, bantu membantu dan saling memberi dan menerima dalam suasana keberterimaan antar anggota masyarakat (ummatan wa sathan).

\section{METODE PENELITIAN}

Pendekatan penelitian ini menggunakan pendekatan kualitatif dengan menggunakan metode studi kasus yang bersifat deskriptif. Pendekatan ini digunakan bertujuan untuk menjelaskan dan menggambarkan mengenai implementasi komponenmaqashidsyariah terhadap kesejahteraan pada karyawan Yayasan Nurul Hayat Surabaya.

Ruang lingkup penelitian ini hanya terbatas pada kebijakan yang berlaku di Yayasan Nurul Hayat Surabaya terhadap kesejahteraan karyawannya.

Informan dipilih sesuai spesifikasi peneliti guna mendapatkan informasi yang dibutuhkan oleh peneliti. Peneliti telah menetapkan tujuh karyawan sebagai informan dikarenakan jawaban hasil wawancara dari ketujuhkaryawan tersebut sudah mewakili pertanyaan peneliti.

Jenis sumber data dalam penelitian ini yaitu data primer (utama) dan data sekunder (penunjang). Data primer diperoleh melalui hasil wawancara dan observasi langsung. Sedangkan data sekunder berasal dari buku-buku yang menjadi referensi bagi peneliti yang berkaitan dengan kesejahteraan perspektif maqashid syariah. Selain itu juga didapatkan dari jurnal-jurnal, artikel, website, dan sumber-sumber lain yang memiliki kaitan yang relevan dengan penelitian.

Tekhnik pengumpulan data yang digunakan peneliti dalam penelitian ini adalah:

1. Wawancara 
Andriana, et al/Jurnal Ekonomi Syariah Teori dan Terapan Vol. 6 No. 3 Maret 2019: 428-445; IMPLEMENTASI KOMPONEN MAQASHID SYARIAH TERHADAP KESEJAHTERAAN PADAKARYAWAN YAYASAN NURUL HAYAT SURABAYA

Metode wawancara semi terstruktur dilakukan. Untuk itu, telah disiapkan beberapa pertanyaan terkait topik yang akan diteliti secara tertulis. Wawancara dilakukan kepada tujuh karyawan yang menjadi informan di Yayasan Nurul Hayat Surabaya.

2. Observasi

Kegiatan observasi merupakan tekhnik pengumpulan data dengan mengamati perilaku manusia, proses kerja, gejala-gejala alam, objekobjek yang dilihat dan hal-hal lain yang diperlukan dalam mendukung penelitian.

3. Dokumentasi

Teknik dokumentasi digunakan untuk memperoleh data-data yang tidak bisa didapatkan dengan teknik wawancara maupun teknik observasi. Teknik dokumentasi diperoleh berupa foto, gambar, bagan, struktur dan catatancatatan yang diperoleh dari subjek penelitian.

4. Rekaman Arsip

Penelitian ini menggunakan tekhnik triangulasi sumber yang dilakukan dengan mengecek keselarasan data hasil wawancara dengan beberapa sumber yaitu membandingkan hasil wawancara antara karyawandi berbagai divisi guna memperoleh keterkaitan data sehingga menghasilkan data yang akurat.

Yin (2009:133) berpendapat tentang tiga macam bentuk teknik analisis yang sering digunakan antara lain penjodohan pola, pembuatan penjelasan, dan analisis deret waktu, sehingga teknik analisis yang digunakan penelitian ini adalah teknik analisis deskriptif atau dapat disebut pembuatan penjelasan yaitu dengan menggunakan metode analisis data dan mendeskripsikan hasil observasi wawancara.

\section{HASIL DAN PEMBAHASAN}

\section{Kesejahteraan}

Dalam Islam kesejahteraan merupakan suatu kondisi dengan kecukupan rizqi halal yang diterimanya, terpenuhinya kebutuhan spiritual bagi segenap anggota keluarganya, merasa qana'ah dengan apa yang diterimanya.

Dengan demikian maka kesejahteraan bukan hanya diukur dari terpenuhinya kebutuhan fisik dan material (makan, minum, pakain, perumahan) saja, melainkan juga terpenuhinya kebutuhan spiritual.

Berdasarkan hasil wawancara seluruh informan mengatakan bahwa mereka sudah merasa sejahtera selama bekerja di Yayasan Nurul Hayat. Karena kebijakan-kebijakan yang diterapkan di Yayasan Nurul Hayat mengutamakan nilainilai keagamannya.

Analisis Hifz Ad-Dien (Memelihara Agama)

Berdasarkan hasil analisis wawancara 
Andriana, et al/Jurnal Ekonomi Syariah Teori dan Terapan Vol. 6 No. 3 Maret 2019: 428-445; IMPLEMENTASI KOMPONEN MAQASHID SYARIAH TERHADAP KESEJAHTERAAN PADAKARYAWAN YAYASAN NURUL HAYAT SURABAYA

kepada beberapa karyawan Yayasan Nurul Hayat menunjukkan bahwa seluruh informan mengatakan terdapat Masjid Nurul Hayat yang letaknya sangat dekat sekali hanya beberapa langkah saja dari Yayasan. Masjid tersebut selalu terjaga kesuciannya karena dibersihkan setiap sehari dua kali dan di dalamnya dilengkapi AC dan kipas, peralatan sholat(mukenah, sarung, dan sajadah) yang selalu bersih dan wangi karena frekuensi pencuciannya setiap satu minggu sekali terkadang empat hari sekali. Seluruh informan juga mengatakan bahwa pimpinan Yayasan selalu menghimbau agar melaksanakan sholat tepat waktu atau tidak menundanunda, dimana ketika adzan sudah berkumandang maka seluruh aktivitas di bidang pekerjaan masing-masing wajib di berhentikan.

Nabi Muhammad SAW bersabda bahwa sholatnya orang munafik adalah mereka yang secara sengaja menundanunda waktu sholat sampai mendekati berakhirnya waktu sholat. Dari Anas bin Malik radhiyallahu'anhu, Nabi Muhammad SAW bersabda

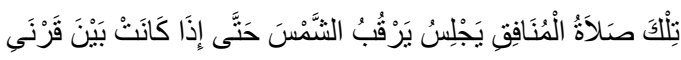

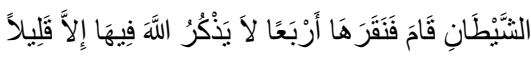

Artinya: itulah shalatnya orang munafik, duduk santai sambil lihat-lihat matahari. Hingga ketika matahari telah berada di antara dua tanduk setan (menjelang terbenam), dia baru mulai shalat, dengan gerakan cepat seperti mematuk 4 kali. Tidak mengingat Allah dalam shalatnya kecuali sedikit. (HR. Muslim 1443 \& Ahmad 11999).

Yayasan Nurul Hayat sebagai lembaga zakat tentunya melayani fasilitas pembayaran zakat bagi karyawannya. Tiap karyawan bebas memilih sesuai keinginnya, tidak ada kebijakan yang mewajibkan karyawan untuk berzakat di Yayasan Nurul Hayat. Sesuai hasil wawancara, sebagian informan lebih memilih zakat di Yayasan Nurul Hayat.

Dari ketujuh informan juga mengatakan bahwa terdapat banyak kajian di Yayasan Nurul Hayat. Setiap pagi hari senin sampai kamis seluruh karyawan wajib setor mengaji di hadapan ustad/ustadzah yang telah mendampingi. Hal tersebut bertujuan untuk mengetahui kemampuan karyawan dalam mengaji misalnya benar atau salah dalam bacaanya dan tajwidnya. Nabi Muhammad SAW bersabda:

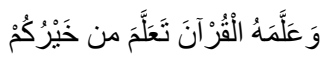

Artinya: sebaik- baik kalian adalah yang mempelajari al-qur'an dan mengajarkannya.(HR.Bukhari (4739), dari Utsman Bin Affan Radhiallahu Anhu)

Adapun kajian tiap minggu yaitu hari rabu dan sabtu dan kajian tiap bulan sekali yaitu MABIT (Malam Bina Iman dan Taqwa), bahwa seluruh karyawan wajib bermalam di Yayasan Nurul Hayat.

Perlindungan terhadap agama yang terakhir yaitu haji atau umroh. ibadah haji merupakan rukun Islam yang kelima. 
Andriana, et al/Jurnal Ekonomi Syariah Teori dan Terapan Vol. 6 No. 3 Maret 2019: 428-445; IMPLEMENTASI KOMPONEN MAQASHID SYARIAH TERHADAP KESEJAHTERAAN PADAKARYAWAN YAYASAN NURUL HAYAT SURABAYA

Selain ibadah haji ada pula ibadah umrah.Bagi yang telah mampu mengerjakan ibadah haji dan umrah sebaiknya ia segera menunaikannya. AlBaqarah[2]:196

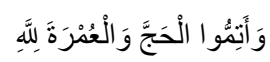

wa atimmul-hajja wal-'umrata lillāh

Artinya:Dan sempurnakalanlah ibadah haji dan umrah kalian karena Allah SWT. (QS AIBaqarah:196, Kementrian Agama RI, 2017:30)

Setiap tahun sekali Yayasan Nurul Hayat selalu memberangkatkan umroh para karyawannya sekitar 8 sampai 10 orang dalam sekali pemberangkatan. Hal ini bertujuan untuk mensejahterakan para karyawannya.

Analisis Hifz An-Nafs (Memelihara Jiwa)

Indikator maqashid syariah yang kedua adalah jiwa. Kondisi terpenuhinya kebutuhan-kebutuhan yang aman dari segala ancaman terhadap jiwa dan raga seperti pemunuhan atas sandang, pangan, dan papan. Nabi Muhammad SAW bersabda perihal penjagaan terhadap jiwa

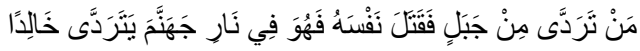

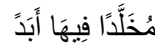

Artinya: Barangsiapa yang menjatuhkan dirinya dari gunung lalu dia membunuh dirinya (mati), maka dia akan berada dalam neraka jahannam dalam keadaan melemparkan diri selama-lamanya.(HR Imam Bukhari)

Seluruh informan menyebuktan bahwa tidak ada pemberian makan kepada karyawan, tetapi ada fasilitas pantry (dapur). Jadi, sebagian karyawan membawa makan (bekal) dari rumah masing-masing. Informan 6 dan 7 mengatakan bahwa ada kantin kejujuran dimana beberapa karyawan menjual makanan lalu disediakan kotak untuk menaruh vang bagi siapa yang ingin membelinya. Selanjutnya untuk transportasi/akomodasi berupa transportasi yang disediakan Yayasan Nurul Hayat dan pemberian uang saku bagi pekerja yang dianjurkan untuk turun lapangan.

Yayasan Nurul Hayat menanggung kesehatan karyawan dan anggota keluarganya melalui BPJS. Syarat BPJS sendiri yaitu bagi karyawan yang sudah memiliki Surat Keputusan (SK). Informan 1, 6, dan 7 jugamendapatkan asuransi Takaful dikarenakan masa bekerjanya selama 3 tahun atau lebih. Seluruh informan merasa puas atau tercukupi dengan adanya BPJS maupun asuransi Takaful.

Analisis Hifz Al-Aql (Memelihara Akal)

Indikator maqashid syariah yang ketiga adalah akal. Salah satu perlindungan terhadap akal yaitu terpenuhinya kebutuhan dalam bidang keilmuan atau pendidikan. Allah berfirman dalam QS AtThaha[20]:1 14

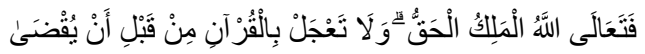

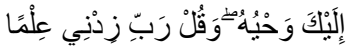

fa ta'ālallāhul-malikul-ḥaqq, wa lā ta'jal bilqur'āni ming qabli ay yuqḍā ilaika wahyuhụ wa qur rabbi zidní 'ilmā 
Andriana, et al/Jurnal Ekonomi Syariah Teori dan Terapan Vol. 6 No. 3 Maret 2019: 428-445; IMPLEMENTASI KOMPONEN MAQASHID SYARIAH TERHADAP KESEJAHTERAAN PADAKARYAWAN YAYASAN NURUL HAYAT SURABAYA

Artinya: Maka Maha Tinggi Allah Raja Yang sebenar-benarnya, dan janganlah kamu tergesa-gesa membaca Al qur'an sebelum disempurnakan mewahyukannya kepadamu, dan katakanlah: "Ya Tuhanku, tambahkanlah kepadaku ilmu pengetahuan". IQS At-Thaha:114, Kementrian Agama RI, 2017:320)

Ilmu tidak hanya untuk diketahui, namun dengan ilmu kita dituntut agar makin bertakwa, beramal sholeh, serta menghindarkan diri dari perbuatan maksiat. Perlindungan akal di Yayasan Nurul Hayat disalurkan melalui pelatihan atau pengembangan ilmu. Informan 1 sebagai manjer HRD mengatakan bahwa pada dasarnya pelatihan-pelatihan yang diadakan guna meningkatkan skill karyawan sesuai dengan bidang pekerjaannya. Adapun pengembangan keilmuan diluar bidang pekerjaan yaitu pelatihan leadership, public speaking, dale carnegie, dan lainnya.

Menurut beberapa informan, Yayasan Nurul Hayat juga sempat memberi beasiswa kepada karyawan yang ingin melanjutkan pendidikan ke jenjang yang lebih tinggi. Dan setiap tahun sekali Yayasan Nurul Hayat memberikan penghargaan "inspiring people"yang merupakan penghargaan untuk karyawan terbaik atau berprestasi.

Analisis Hifz An-Nasl (Memelihara Keturunanl)

Indikator maqashid syariah yang keempat adalah keturunan. Sebagai penjagaan terhadap keturunan maka Islam mengharamkan perzinaan. Allah berfirman pada QS Al-Isra[17]:32

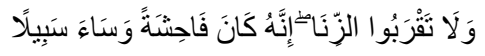

wa lā taqrabuz-zinā innahụ kāna fāḥisyah, wa sā ‘a sabilā

Artinya: Dan janganlah kamu mendekati zina; sesungguhnya zina itu adalah suatu perbuatan yang keji. Dan suatu jalan yang buruk. IQS Al-Israa[17]:32, Kementrian Agama Rl, 2017:285)

Di Yayasan Nurul Hayat tidak ada larangan bagikaryawan yang ingin menikah. Dan tidak ada batasan umur atau minimal masa bekerja bagi yang ingin menikah. Yayasan Nurul Hayat memberikan kebebasan pada karyawan nya dalam memenuhi hak nya untuk segeraberkeluarga atau menikah. Bahkan Yayasan Nurul Hayat memberikan fasilitas bus sebagai transportasi karyawan lainnya untuk mendatangi pernikahan jika lokasi nya di luar kota. Dan Yayasan Nurul Hayat juga memberikan hadiah pernikahan.

Tidak hanya memberikan ilmu pada karyawan saja, Yayasan Nurul Hayat juga membiayai anak dari karyawan jika akan daftar sekolah. Hal ini berguna untuk melanjutkan generasi di keluarga.

Seluruh informan menyatakan bahwa adanya cuti hamil dan melahirkan bagi karyawan yang sedang hamil atau melahirkan. Cuti tersebut selama 2 bulan. Untuk karyawan laki-laki yang istrinya 
Andriana, et al/Jurnal Ekonomi Syariah Teori dan Terapan Vol. 6 No. 3 Maret 2019: 428-445; IMPLEMENTASI KOMPONEN MAQASHID SYARIAH TERHADAP KESEJAHTERAAN PADAKARYAWAN YAYASAN NURUL HAYAT SURABAYA

sedang hamil dan menjelang melahirkan diberi cuti selama 7 hari untuk menemani istri nya. Tidak ada fasilitas bersalin secara khusus yang diberikan pihak Yayasan Nurul Hayat dikarenakan sesuai ketentuan yang berlaku, seluruhnya telah di alihkan melalui BPJS. Dari ketujuh informan sangat setuju dan puas atas kebijakan-kebijakan diatas, karena bermanfaat bagi pemenuhan kebutuhan hidup tiap karyawan.

Analisis Hifz AL-Maal (Melihara Harta)

Indikator maqashid syariah yang kelima adalah harta. Hal ini berhubungan dengan gaji yang diterima karyawan dan bagaimana cara mereka mengatur pengeluarannya. Allah SWT berfiman pada QS Al-Baqarah [2]:262

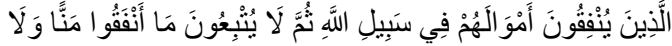

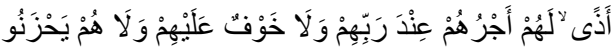

allażīna yunfiqụna amwālahum fì sabilillāhi summa lā yutbi'una mā anfaqụ mannaw wa lā ażal lahum ajruhum 'inda rabbihim, wa lā khaufun'alaihim wa lā hum yahzanụn

Artinya: Orang-orang yang menafkahkan hartanya di jalan Allah, kemudian mereka tidak mengiringi apa yang dinafkahkannya itu dengan menyebut-nyebut pemberiannya dan dengan tidak menyakiti (perasaan si penerima), mereka memperoleh pahala di sisi Tuhan mereka. Tidak ada kekhawatiran terhadap mereka dan tidak (pula) mereka bersedih hati. (QS Al-Baqarah[2]:262, Kementrian Agama RI, 2017:44)

Allah SWT menjelaskan cara berinfak yang direstui Allah dan yang berhak mendapat pahala berlipat ganda yaitu orang yang menginfakkan hartanya di jalan Allah dalam segala bentuk kebaikan, kemudian tidak pula membanggakannya, dan tidak menyakiti perasaan penerimanya.

Nabi Muhammad SAW memerintahkan memberikan upah sebelum keringat si pekerja kering. Dari Abdullah bin Umar, Nabi Muhammad SAW bersabda

$$
\text { أَعْطُو الأَجِيرَ أَجْرَهُ قَبْلَ أَنْ يَجِفََّ عَرَفُهُ }
$$

Artinya: Berikan kepada seorang pekerja upahnya sebelum keringatnya kering (HR. Ibnu Majah, shahih)

Makna hadits diatas adalah bagi para pimpinan atau pemilik perusahaan bersegeralah memenuhi hak si pekerja setelah selesainya pekerjaan, begitu juga bisa dimaksud jika telah ada kesepakatan pemberian gaji setiap bulan.

Seluruh informan merasa cukup dan bersyukur atas gaji yang diterimanya. Karena selama bekerja di Yayasan Nurul Hayat, beberapa informan telah berhasil membeli barang-barang yang diinginkan untuk memenuhi kebutuhan hidupnya yaitu seperti membeli handphone, motor, rumah, dan pengeluaran-pengeluran lainnya.

Tidak hanya gaji, seluruh informan juga menjelaskan adanya bonus-bounus lain seperti bonus akhir tahun, THR, dan bonus Idul Adha. Dan terdapat tunjangan khusus bagi karyawan berprestasi yang diberikan tiap tahun sekali. 
Andriana, et al/Jurnal Ekonomi Syariah Teori dan Terapan Vol. 6 No. 3 Maret 2019: 428-445; IMPLEMENTASI KOMPONEN MAQASHID SYARIAH TERHADAP KESEJAHTERAAN PADAKARYAWAN YAYASAN NURUL HAYAT SURABAYA

\section{KESIMPULAN}

Berdasarkan

sebelumnya, kesimpulan yang dapat diambil dari hasil penelitian ini adalah seluruh informan merasakan kesejahteraan selama bekerja di Yayasan Nurul Hayat. Berikut adalah hasil penelitannya:

1. Kesejahteraan perspektif maqashidsyariah dari segi pemenuhan kebutuhan pemeliharaan agama (hifz ad-dien) yaitu seluruh karyawan menyatakan adanya perintah agar karyawan memberhentinkan aktivitasnya di saat adzan telah berkumandang dan segera melaksanakan sholat tepat waktu. Karyawan juga di mudahkan dengan adanya masjid yang letaknya sangat dekat. Masjid selalu terjaga kesuciannya dan kebersihan alat sholat selalu diperhatikan, frekuensi pencuciannya seminggu sekali terkadang empat hari sekali. Yayasan Nurul Hayat setiap tahun sekali juga memberangkatkan

umroh

karyawannya, sekali pemberangkat sekitar 8 sampai 10 orang. Dan adanya pelaksanaan kajian bulanan, mingguan, dan harian.

2. Kesejahteraan perspektif maqashidsyariah dari segi pemenuhan kebutuhan pemeliharaan jiwa (hifz an-nafs), Yayasan Nurul Hayat menyediakan fasilitas atau ruangan untuk makan berupa pantry (dapur). Mengenai halhal yang dibutuhkan oleh karyawan untuk menghilangkan kesulitan yang tejadi kedepannya, karyawan mendapatkan asuransi yaitu asuransi Takaful, BPJS Kesehatan dan Ketenagakerjaan. Yayasan Nurul Hayat juga disediakan tranportasi dan diberi uang saku bagi karyawan yang diperintah untuk terjun ke lapangan.

3. Kesejahteraan perspektif maqashidsyariah dari segi pemenuhan kebutuhan pemeliharaan akal (hifz al-aql), seluruh informan mengatakan penting dengan adanya pelatihan-pelatihan. Yayasan Nurul Hayat memberikan pelatihan kepada karyawan baru, dan workshop atau seminar lainnya seperti leadership, public speaking, dalecarnegie, dan lainnya. Yayasan Nurul Hayat juga memberikan beasiswa bagi karyawan dan setiap tahun nya memberikan penghargaan bagi karyawan berprestasi.

4. Kesejahteraan perspektif maqashidsyariah dari segi pemenuhan kebutuhan pemeliharaan keturunan (hifz an-nasl), informan mengatakan bahwa tidak ada larangan menikah bagi karyawan, dan tidak ada syarat tertentu untuk menikah. Pemberian cuti hamil dan melahirkan selama 2 bulan dan bagi karyawan laki-laki 
Andriana, et al/Jurnal Ekonomi Syariah Teori dan Terapan Vol. 6 No. 3 Maret 2019: 428-445; IMPLEMENTASI KOMPONEN MAQASHID SYARIAH TERHADAP KESEJAHTERAAN PADAKARYAWAN YAYASAN NURUL HAYAT SURABAYA

yang istrinya melahirkan mendapatkan cuti selama 7 hari untuk menemani istri nya. Yayasan Nurul Hayat juga membantu pembiayaan anak dari karyawan jika akan masuk sekolah.

5. Kesejahteraan perspektif maqashidsyariah dari segi pemenuhan kebutuhan pemeliharaan harta (hifz al-maal), Yayasan Nurul Hayat selalu tepat waktu dalam pemberian gaji. Lalu karyawan juga merasa puas dengan disediakan bonus-bonus atau tunjangan yang diberikan kepada karyawan seperti bonus akhir tahun, bonus Idul Adha, dan THR.

\section{SARAN}

1. Pihak Terkait

Perlunya disediakan fasilitas kesehatan seperti ruangan bagi karyawan yang tiba-tiba sakit atau disediakan Pertolongan Pertama Pada Kecelakaan (P3K).

\section{Bagi Peneliti Selanjutnya}

Penelitian ini dapat digunakan sebagai bahan referensi bagi penelitian selanjutnya. Dapat meneliti topik yang sama dengan detail penelitian yang lebih mendalam misalnya menambah indikatorindikator kesejahteraan sehingga didapatkan penelitian kesejahteraan karyawan yang lebih komprehensif dengan aspek maqashidsyariah.

\section{DAFTAR PUSTAKA}

Al-Qur'an Tafsir dan Terjemahannya. 1978. Bandung: Firma Sumatra Bandung Lembaga Penterjemah dan Tafsir AlQur'an.

Ahmed Raja Ahmed Haj Ali, Kamaruzaman Bin Noordin, and Meguellati Achour. 2018. The Islamic Approach of Obligations in Mutual Relations between Employee and Employer. International Journal of Ethics and Systems, Vol. 34 Issue: 3, pp.338351.

Duhriah. 2015. Tingkatan-tingkatan Maqashid Al-Syariah: al-Dharruriyyat, al-Hajiyyat dan al-Tahsiniyyat. Jurnal Vol. 01 No. 1 Januari-Juni 2015.

Fauzia, Ika Yunia dan Abdul Kadir Riyadi: 2014. Prinsip Dasar Ekonomi Islam Perspektif Maqashid Al-Syariah. Jakarta: Kencana.

Hidayat, Muhammad. 2010. An Introduction to The Sharia Economic. Jakarta: Zikrul Hakim. Kementrian Agama Republik Indonesia. 2017.

Listiawati, 2012. Prinsip Dasar Ekonomi Islam. Palembang: Rafah Press.

Mursi, Abdul Hamid. 1997. Sumber Daya Manusia yang Produktif Pendekatan Al-Qur'an dan Sains. Jakarta: Gema Insani Press.

Pusat Pengkajian dan Pengembangan Ekonomi Islam (P3EI). 2008. Ekonomi Islam. Jakarta: PT. Raja Grafindo 
Andriana, et al/Jurnal Ekonomi Syariah Teori dan Terapan Vol. 6 No. 3 Maret 2019: 428-445; IMPLEMENTASI KOMPONEN MAQASHID SYARIAH TERHADAP KESEJAHTERAAN PADAKARYAWAN YAYASAN NURUL HAYAT SURABAYA

Wibowo, Arif. 2012. Maqashid Asy Syariah:

The Ultimate Objective of Syariah. Islamic Finance.

Yin, Robert K. 2009. Studi Kasus: Desain dan

Metode. Jakarta: Raja Grafindo

Persada.

Zadjuli, Suroso Imam. 2008. Prinsip-prinsip

Ekonomi Islam. Surabaya: Fakultas

Ekonomi Universitas Airlangga. 